\title{
PEMANFAATAN Starbio, Aspergilus niger DAN Trichoderma viride PADA TONGKOL JAGUNG TERHADAP KECERNAAN SERAT KASAR DAN PROTEIN KASAR PADA DOMBA JANTAN LOKAL LEPAS SAPIH
}

\author{
(Utilization Starbio, Aspergillus niger and Trichoderma viride on the Corn Cobs Crude \\ Protein and Crude Fiber Digestibility on Weaning Local Ram)
}

\author{
Rico Rifki Yudiar ${ }^{1}$, Ma'ruf Tafsin ${ }^{2}$, Nevy Diana Hanafi \\ 1. Mahasiswa Program Studi Peternakan Fakultas Pertanian Universitas SumateraUtara \\ 2. Staf Pengajar Program Studi Peternakan Fakultas Pertanian Universitas Sumatera Utara
}

\begin{abstract}
Potential byproducts of fermentation of corn cobs as feedstock complete feed sheep to increase crude protein and crude fiber digestibility. This study aims to determine the effect of complete feed by product of the corn cob digestibility of crude fiber and crude protein. The experiment was conducted at the Faculty of Agriculture at the University of North Sumatra, July to September 2013. The design used in this study was a completely randomized design (CRD) with five treatments. The results showed the average digestibility of crude protein was highest in treatment P1 (fermented corn cobs starbio 0.5\%) and the lowest at P0 treatment (corn cobs without fermentation) whereas the highest mean digestibility of crude fiber in the treatment P4 (fermented corn cob, 25\% Aspergillus niger and Trichoderma viride 0.25\%). Fermented corn cob with bio-actifator give influence significantly different compared with corn cobs without fermentation in improving the digestibility of crude protein and crude fiber digestibility. The conclusion were bio-actifator Starbio give a very different effect in increasing the high apparent digestibility of crude protein digestibility of crude fiber but not given a significantly different effect compared with other bio-actifatorThe conclusion is utilization of corn cob fermented with bio-activator give influence significantly different compared with corn cobs without fermentation in improving the digestibility of crude protein and crude fiber digestibility. Bio-activator Starbio give significantly different influence in increasing the digestibility of crude protein digestibility but crude fiber digestibility not give a significantly different effect compared with other bio-activator
\end{abstract}

Keywords : Corn Cobs, Fermentation, Microbial, Digestibility, Weaning Local Ram.

\begin{abstract}
ABSTRAK
Potensi hasil samping tongkol jagung fermentasi sebagai bahan baku pakan komplit domba untuk meningkatkan kecernaan protein kasar dan serat kasar. Penelitian ini bertujuan untuk mengetahui pengaruh pemberian pakan komplit hasil samping tongkol jagung terhadap kecernaan serat kasar dan protein kasar. Penelitian dilaksanakan di Fakultas pertanaian Univesitas Sumatera Utara pada bulan Juli sampai dengan September 2013. Rancangan yang digunakan dalam penelitaian ini adalah rancangan acak lengkap (RAL) dengan 5 perlakuan. Hasil penelitian menunjukkan rataan kecernaan protein kasar tertinggi terdapat pada perlakuan P1(tongkol jagung fermentasi 0,5\% starbio) dan terendah pada perlakuan P0(tongkol jagung tanpa fermentasi) sedangkan rataan kecernaan serat kasar tertinggi pada perlakuan P4(tongkol jagung fermentasi ,25\% Aspergillus niger dan 0,25\% Trichoderma viride). Tongkol jagung yang difermentasi dengan bioaktifator memberikan pengaruh yang sangat berbeda nyata dibandingkan dengan tongkol jagung tanpa fermentasi dalam meningkatkan kecernaan protein kasar dan kecernaan serat kasar. Kesimpulan penelitian adalah bioaktifator Starbio memberikan pengaruh yang sangat berbeda nyata tinggi dalam meningkatkan kecernaan protein kasar tetapi untuk kecernaan serat kasar tidak memberikan pengaruh yang berbeda nyata dibandingkan dengan bioaktifator lainnya. Kesimpulan penelitian ini adalah penggunaan tongkol jagung yang difermentasi dengan bioaktifator memberikan pengaruh yang sangat berbeda nyata dibandingkan dengan tongkol jagung tanpa fermentasi dalam meningkatkan kecernaan protein kasar dan kecernaan serat kasar. Bioaktifator Starbio memberikan pengaruh yang sangat berbeda nyata dalam meningkatkan kecernaan protein kasar tetapi untuk kecernaan serat kasar tidak memberikan pengaruh yang berbeda nyata dibandingkan dengan bioaktifator lainnya
\end{abstract}

Kata kunci : Tongkol Jagung, Fermentasi, Mikroba, Kecernaan, Domba Lokal 


\section{PENDAHULUAN}

Ternak domba merupakan subsektor peternakan sebagai salah satu bagian yang memberikan pengaruh sebagai sumber protein hewani yang sangat potensial untuk dikembangkan. Dengan demikian peluang pasarnya selalu tersedia setiap saat dan selalu meningkat setiap tahun seiring dengan pertambahan jumlah penduduk dan meningkatnya kebutuhan gizi. Pada dasarnya, antara persediaan dan permintaan daging di Indonesia terjadi kesenjangan yang cukup besar (Tomaszeweska,1993).

Kebutuhan protein hewani masyarakat Indonesia terus meningkat seiring dengan pertambahan penduduk dan meningkatnya kesadaran masyarakat akan pentingnya zat gizi. Sehingga peternakan merupakan sektor yang berperan sangat penting dalam penyediaan kebutuhan pangan khususnya kebutuhan protein hewani tersebut. Untuk mengatasi hal tersebut maka perlu dicari suatu pakan alternatif yang dapat menggantikan rumput sebagai pakan ternak salah satunya adalah tongkol jagung. Pemanfaatan tongkol jagung sebagai komponen ransum domba belum banyak digunakan karena sifat fisik yang keras ditambah dengan nilai nutrisinya yang rendah, sehingga diperlukan upaya pengolahan lebih lanjut untuk memperbaiki nilai nutrisinyaan. Salah satu metode pengolahan yang dapat dilakukan adalah pemanfaatan jasa teknologi fermentasi menggunakan beberapa bioaktifator yang ada.

Dengan fermentasi komposisi protein tongkol jagung yang secara umum mengalami peningkatan dari $3 \%$ menjadi $6,1 \%$ dan diikuti penurunan kadar serat kasar. tongkol jagung tanpa fermentasi memiliki kandungan serat kasar yang lebih tinggi sebesar 23,8\% dibandingkan dengan yang difermentasi dengan Starbio, Aspergillus niger, Trichoderma viride dan gabungan Aspergillus niger dengan Trichoderma viride yang mempunyai kandungan serat kasar berturut-turut adalah 17,1\%, 17,6\%, 17,9\% dan 17\%. (Hasil Lab.Nutrisi dan Bahan Pakan Ternak,2014)

Berdasarkan uraian penulis melakukan penelitian berjudul pemanfaatan tongkol jagung dengan fermentasi bioaktifator Starbio, Aspergillus niger dan Trichoderma viride terhadap kecernaan serat kasar dan protein kasar pada domba lokal jantan.

\section{BAHAN DAN METODE PENELITIAN}

\section{Tempat dan Waktu Penelitian}

Penelitian telah dilaksanakan di Laboratorium Biologi Ternak Program Studi Peternakan Fakultas Pertanian Universitas Sumatera Utara Medan. Berlangsung selama 3 bulan mulai bulan Juli sampai September 2013. 


\section{Bahan dan Alat Penelitian}

Bahan yang digunakan antara lain: Domba lokal jantan lepas sapih sebanyak 20 ekor. Bahan pakan yang diberikan terdiri atas : tongkol jagung dan bioaktifator sebagai fermentor serta konsentrat terdiri atas: dedak halus, bungkil kedelai, ultra mineral dan garam. Bahan pakan difermentasikan dengan Starbio, Aspergilus niger dan Trichoderma viride. Obatobatan seperti obat cacing (Kalbazen), anti bloat untuk obat kembung, air minum, desinfektan (Rodalon) dan obat tradisional.

Alat yang digunakan antara lain: Kandang terdiri atas kandang individu 20 unit dengan ukuran 1 x $0,5 \mathrm{~m}^{2}$ beserta perlengkapannya, ember sebanyak 20 buah sebagai tempat pakan dan 20 buah tempat minum, timbangan untuk berkapasitas $150 \mathrm{~kg}$ dengan kepekaan $50 \mathrm{~g}$, timbangan berkapasitas $2 \mathrm{~kg}$ dengan kepekaan $10 \mathrm{~g}$, terpal plastik, goni plastik sebagai tempat pakan, alat penerangan, grinder, mixer, alat tulis, alat pembersih kandang dan thermometer.

\section{Metode Penelitian}

Rancangan percobaan yang digunakan dalam penelitian ini adalah secara experimental dengan menggunakan Rancangan Acak Lengkap (RAL) dengan 5 perlakuan dan 4 ulangan. Adapun perlakuan yang diberikan adalah :

$\mathrm{P}_{0} \quad$ : Tongkol jagung fermentasi tanpa bioaktifator (kontrol)

$\mathrm{P}_{1} \quad$ : Tongkol jagung fermentasi dengan Starbio 0,5\%

$\mathrm{P}_{2} \quad$ : Tongkol jagung fermentasi dengan Aspergillus niger $0,5 \%$

$\mathrm{P}_{3} \quad$ : Tongkol jagung fermentasi dengan Trichoderma viride $0,5 \%$

$\mathrm{P}_{4} \quad$ : Tongkol jagung fermentasi dengan Aspergillus niger 0,25\% dan Trichoderma viride $0,25 \%$.

Model Matematik RAL (Furqon,2008) adalah sebagai berikut:

$$
\mathrm{Y}_{\mathrm{ij}}=\mu+\sigma_{\mathrm{i}}+\varepsilon_{\mathrm{ij}}
$$

Keterangan:

Yij = nilai pengamatan pada perlakuan ke-i ulangan ke $\mathrm{j}$

$\mathrm{i} \quad=1,2,3,4,5$ (perlakuan)

$\mathrm{j} \quad=1,2,3,4$ (ulangan)

$\mu \quad=$ nilai tengah umum

$\sigma_{\mathrm{i}} \quad=$ pengaruh perlakuan ke-i

$\varepsilon_{\mathrm{ij}} \quad=$ efek galat percobaan pada perlakuan ke-i, ulangan ke-j 
Pakan yang digunakan merupakan fermentasi tongkol jagung dengan bioaktifator, konsentrat berupa dedak halus, bungkil kedelai, ultra mineral, garam dan molasses.

Adapun susunan ransum komplit dan kandungan beberapa nutrisi dalam ransum yang disusun dapat dilihat pada Tabel 1 dibawah ini :

Tabel 1. Susunan Ransum Komplit Selama Penelitian

\begin{tabular}{lrrrrr}
\hline \multicolumn{1}{c}{ Bahan pakan } & \multicolumn{5}{c}{ Perlakuan (\%) } \\
\cline { 2 - 6 } & $\mathrm{P} 0$ & $\mathrm{P} 1$ & $\mathrm{P} 2$ & $\mathrm{P} 3$ & $\mathrm{P} 4$ \\
\hline Tongkol jagung tanpa perlakuan (kontrol) & 50 & 0 & 0 & 0 & 0 \\
Tongkol jagung + Starbio & 0 & 50 & 0 & 0 & 0 \\
Tongkol jagung + Aspegillus niger & 0 & 0 & 50 & 0 & 0 \\
Tongkol jagung + Trichoderma viride & 0 & 0 & 0 & 50 & 0 \\
Tongkol jagung + Aspergillus niger dan & 0 & 0 & 0 & 0 & 50 \\
Trichoderma viride & & & & & \\
Bungkil inti sawit & 30 & 30 & 30 & 30 & 30 \\
Dedak padi & 9 & 9 & 9 & 9 & 9 \\
Molases & 6 & 6 & 6 & 6 & 6 \\
Urea & 3 & 3 & 3 & 3 & 3 \\
Garam & 1 & 1 & 1 & 1 & 1 \\
Ultra mineral & 1 & 1 & 1 & 1 & 1 \\
\hline Jenis nutrisi & \multicolumn{5}{c}{ Kandungan nutrisi $(\%)$} \\
\hline Protein Kasar (PK) & 15,1 & 15,9 & 15,2 & 15,4 & 15,8 \\
Serat Kasar (SK) & 23,8 & 23,1 & 23,6 & 23,4 & 23,2 \\
\hline
\end{tabular}

Cara pembuatan fermentasi tongkol jagung dilakukan dengan penjemuran tongkol jagung sebelum diperkecil partikelnya dengan grinder setelah itu tongkol jagung disiram dengan air yang telah dilarutkan urea dan bioaktifator (Starbio, Aspergillus niger, Trichoderma viride) hingga merata dengan kelembapan $60 \%$ kemudian tongkol jagung dimasukkan kedalam plastic dengan memberi lubang kecil sebagai oksigen dan terakhir tongkol jagung difermentasi selama 10 hari (Rohaeni et al., 2006).

\section{Analisis Data}

Semua data pada peubah yang diamati yang meliputi serat kasar dan protein kasar akan dihitung berdasarkan rancangan percobaan dengan menggunakan Rancangan Acak Lengkap (RAL) Non Faktorial. Apabila diantara perlakuan terdapat perbedaan yang nyata atau sangat nyata, maka akan dilanjutkan dengan menggunakan Uji Ortogonal Kontras yang dikemukakan Hanafiah (2002). Dari 5 perlakuan dapat disusun 4 pembandingan linier ortogonal kontras sebagai berikut: 
Tabel 2. Susunan kontras penelitian

\begin{tabular}{ll}
\hline Perlakuan & \multicolumn{1}{c}{ Keterangan } \\
\hline P0 vs P1P2P3P4 & Ransum tongkol jagung tanpa fermentasi dibandingkan dengan \\
& ransum tongkol jagung fermentasi Starbio, Aspergillus niger, \\
& Trichoderma viride dan gabungan Aspergillus niger dengan \\
& Trichoderma viride \\
& Ransum tongkol jagung fermentasi Starbio dibandingkan dengan \\
& ransum tongkol jagung Aspergillus niger, Trichoderma viride dan \\
P1 vs P2P3P4 & gabungan Aspergillus niger dengan Trichoderma viride \\
& Ransum tongkol jagung fermentasi Aspergillus niger \\
dibandingkan dengan ransum tongkol jagung Trichoderma viride & dangabungan Aspergillus niger dengan Trichoderma viride \\
& Ransum tongkol jagung fermentasi Trichoderma viride \\
& dibandingkan dengan ransum tongkol jagung gabungan \\
& Aspergillus niger dengan Trichoderma viride \\
\hline
\end{tabular}

\section{Parameter Penelitian}

\section{Kecernaan Serat Kasar (KcSK)}

Kecernaan serat kasar dapat diukur dengan menghitung berdasarkan rumus:

$$
\mathrm{KcSK}=\frac{\text { SK konsumsi }- \text { SK feses }}{\text { SK konsumsi }} \times 100 \%
$$

Konsumsi dari pengeluaran feses (SK) diperoleh dalam jangka waktu pengukuran selama periode koleksi yaitu satu minggu (Wahyuni, 2009).

\section{Kecernaan Protein Kasar (KcPK)}

Kecernaan protein kasar dapat diukur dengan menghitung berdasarkan rumus:

$$
\mathrm{KcPK}=\frac{\text { PK konsumsi }-\mathrm{PK} \text { feses }}{\text { PK konsumsi }} \times 100 \%
$$

Konsumsi dan pengeluaran feses (PK) diperoleh dalam jangka waktu pengukuran selama periode koleksi yaitu selama satu minggu (Wahyuni, 2009).

\section{HASIL DAN PEMBAHASAN}

Rekapitulasi hasil penelitian dari pemanfaatan tongkol jagung dengan fermentasi bioaktifator Starbio, Aspergillus niger, dan Trichoderma viride terhadap kecernaan serat kasar dan protein kasar pada domba jantan lokal lepas sapih dapat dilihat pada Tabel 2.

Rekapitulasi hasil penelitian diperoleh bahwa kecernaan protein kasar tertinggi terdapat pada perlakuan P1 (fermentasi tongkol jagung dengan starbio) dengan nilai 70.56\% dan kecernaan protein terendah terdapat pada perlakuan P0 (tongkol jagung tanpa fermentasi) dengan nilai $65.18 \%$ dan kecernaan serat kasar tertinggi terdapat pada perlakuan terdapat 
pada perlakuan P4 (fermentasi tongkol jagung gabungan Aspergillus niger dan Trichoderma viride) dengan nilai $45.88 \%$ dan kecernaan serat kasar terendah terdapat pada perlakuan P0 (tongkol jagung tanpa fermentasi) dengan nilai 39.64\%.

Tabel 2. Rekapitulasi hasil penelitian dari pemanfaatan tongkol jagung dengan fermentasi bioaktifator Starbio, Aspergillus niger, dan Trichoderma viride terhadap kecernaan serat kasar dan protein kasar pada domba jantan lokal lepas sapih

\begin{tabular}{ccc}
\hline \multirow{2}{*}{ Perlakuan } & \multicolumn{2}{c}{ Peubah yang diamati (\%) } \\
\cline { 2 - 3 } & Kecernaan protein kasar & Kecernaan serat kasar \\
P0 & $65.18 \pm 0.13$ & $39.64 \pm 0.64$ \\
P1 & $70.56 \pm 0.06$ & $43.67 \pm 3.56$ \\
P2 & $67.72 \pm 0.79$ & $44.36 \pm 1.33$ \\
P3 & $67.83 \pm 0.40$ & $44.07 \pm 0.46$ \\
P4 & $68.22 \pm 0.77$ & $45.88 \pm 0.61$ \\
\hline Rataan & 67,90 & 43.52 \\
\hline
\end{tabular}

Tabel 3. Rataan kecernaan protein kasar dan serat kasar selama penelitian

\begin{tabular}{|c|c|c|}
\hline \multirow{2}{*}{ Perlakuan } & Kec.Protein & Kec.Serat \\
\hline & F Hit & F Hit \\
\hline P0vsP1P2P3P4 & $132.11 * *$ & $24.47 * *$ \\
\hline $\mathrm{P} 1$ vs $\mathrm{P} 2 \mathrm{P} 3 \mathrm{P} 4$ & $74.65 * *$ & $1.17^{\mathrm{tn}}$ \\
\hline P2 vs P3P4 & $0.88^{\text {tn }}$ & $0.32^{\text {tn }}$ \\
\hline P3 vs P4 & $1.07^{\mathrm{tn}}$ & $2.13^{\mathrm{tn}}$ \\
\hline
\end{tabular}

\section{Kecernaan Protein Kasar}

Kecernaan merupakan bagian dari pakan yang tidak diekskresikan dalam feses (Tillman et al., 1998). Kecernaan protein kasar dihitung dengan cara protein kasar konsumsi dikurangi protein kasar feses dibagi protein kasar konsumsi dikalikan seratus persen. Data kecernaan protein kasar domba.

Rataan kecernaan protein kasar yang tertinggi terdapat pada perlakuan P1 yaitu sebesar $70.56 \%$ sedangkan yang terendah pada perlakuan P0 yaitu sebesar $65.18 \%$. Analisis keragaman kecernaan protein menunjukkan bahwa pemberian ransum tongkol jagung fermentasi memberikan pengaruh yang sangat berbeda nyata terhadap kecernaan protein kasar feses domba dengan berbagai jenis fermentasi dimana hal ini disebabkan oleh pakan komplit hasil samping tongkol jagung yang diberikan kepada ternak domba memiliki kandungan nutrisi yang lengkap, sehingga dapat meningkatkan daya cerna pakan itu sendiri dan yang mempengaruhi daya cerna tersebut adalah komposisi pakan. Untuk mengetahui 
pengaruh tongkol jagung fermentasi Starbio, Aspergillus niger, Trichoderma viride terhadap kecernaan protein kasar pada domba setiap perlakuan maka dilakukan uji ortogonal kontras yang dapat di lihat pada Tabel 3.

Tabel 3 menunjukkan bahwa kecernaan protein kasar pada perlakuan P0 (ransum tongkol jagung tanpa difermentasi) nyata lebih rendah $(\mathrm{P}<0.01)$ dibandingkan dengan perlakuan P1, P2, P3, P4 yaitu ransum tongkol jagung yang difermentasi dengan Starbio, Aspergillus niger, Trichoderma viride, dan gabungan Aspergillus niger dengan Trichoderma viride. Hal ini memberikan indikasi bahwa bioaktifator tersebut mengandung mikroba proteolitik yang akan menghasilkan enzim protease yang dapat merombak protein menjadi polipetida yang selanjutnya menjadi peptide sederhana. Hasil penelitian menggambarkan bahwa komposisi protein tongkol jagung yang telah difermentasi dengan menggunakan bioaktifator Starbio, Aspergillus niger, Trichoderma viride, dan gabungan Aspergillus niger dengan Trichoderma viride secara umum lebih baik dibandingkan dengan pakan tongkol tanpa fermentasi.

Uji ortogonal kontras menunjukkan bahwa kecernaan protein kasar pada perlakuan P1 memberikan pengaruh yang sangat nyata lebih tinggi $(\mathrm{P}<0.01)$ dibandingkan perlakuan $\mathrm{P} 2$, P3 dan P4. Uji tersebut juga menunjukkan bahwa perlakuan P1 ransum tongkol jagung dengan fermentasi menggunakan Starbio lebih baik dibandingkan perlakuan P2, P3, dan P4 yang difermentasi menggunakan Aspergillus niger, Trichoderma viride, dan gabungan Aspergillus niger dengan Trichoderma viride. Hal ini dikarenakan probiotik Starbio merupakan kumpulan mikroorganisme (mikroba probilitik, selulotik, lignolitik, lipolitik dan aminolitik serat nitrogen fiksasi nin simbiosis) berbeda dengan Aspergillus niger dan Trichoderma viride yang hanya merupakan kapang. Hasil analisa laboratorium menunjukkan perlakuan P1 memiliki nilai protein kasar yang lebih tinggi dibandingkan dengan P2, P3 dan P4. Hal ini sesuai dengan pernyataan Tillman et al., (2005) bahwa kecernaan protein kasar tergantung pada kandungan protein dalam pakan. Pakan yang kandungan proteinnya rendah, umumnya mempunyai kecernaan yang rendah pula dan sebaliknya. Tinggi rendahnya kecernaan protein tergantung pada kandungan protein bahan pakan dan banyaknya protein yang masuk dalam saluran pencernaan.

Hasil penelitian diperoleh bahwa kecernaan protein kasar pada perlakuan P2 ransum tongkol jagung dengan fermentasi 0,5\% Aspergillus niger tidak memberikan pengaruh nyata ( $\mathrm{P}>0.05)$ dibandingkan dengan perlakuan P3, P4 yaitu fermentasi tongkol jagung dengan Trichoderma viride dan tongkol jagung fermentasi 0,25\% Aspergillus niger dan 0,25\% 
Trichoderma viride. Demikian halnya juga dengan perlakuan P3 juga memberikan pengaruh yang tidak nyata terhadap perlakuan P4 yaitu tongkol jagung fermentasi 0,25\% Aspergillus niger dan 0,25\% Trichoderma viride. Hal ini dapat disebabkan oleh mikroorganisme yang sama dalam proses fermentasi, sehingga mikroba bekerja dalam kondisi yang sama pula karena kedua bioaktifator tersebut bersifat memecah selulosa (selulolitik) untuk meningkatkan nutrisi pakan (Hardjo et al., 1989).

\section{Kecernaan Serat Kasar}

Kecernaan serat kasar pakan pada domba lokal jantan dihitung dengan cara serat kasar dari konsumsi dikurangi serat kasar feses dibagi serat kasar konsumsi dikalikan seratus persen

Rataan kecernaan serat kasar feses domba jantan lokal sebesar 43,52\%. Rataan kecernaan serat kasar feses pada domba tertinggi diperoleh dari perlakuan P2 sebesar 44,32\% dan kecernaan serat kasar feses terendah diperoleh dari perlakuan P0 yaitu sebesar 39,64\%. Menurut Sutardi (1980) nilai kecernaan suatu serat kasar dari suatu pakan dapat menentukan kualitas pakan tersebut.

Pengaruh pemanfaatan tongkol jagung dengan bioaktifator Starbio, Aspergillus niger dan Trichoderma viride dalam pakan terhadap kecernaan feses domba selama penelitian, maka dilakukan analisis keragaman. Analisa keragaman kecernaan serat kasar menunjukkan bahwa pemberian tongkol jagung fermentasi Starbio, Aspergillus niger, Trichoderma viride memberi pengaruh yang sangat berbeda nyata terhadap kecernaan serat kasar domba. Untuk mengetahui pengaruh tongkol jagung fermentasi Starbio, Aspergillus niger, Trichoderma viride terhadap kecernaan serat kasar pada domba setiap perlakuan maka dilakukan uji ortogonal kontras yang dapat dilihat pada Tabel 3.

Uji kontras ortogonal menunjukkan bahwa kecernaan serat kasar pada perlakuan P0 (ransum tongkol jagung tanpa difermentasi) memberikan pengaruh yang sangat berbeda nyata $(\mathrm{P}<0,01)$ dibandingkan dengan perlakuan $\mathrm{P} 1, \mathrm{P} 2, \mathrm{P} 3$ dan $\mathrm{P} 4$ yaitu pakan tongkol jagung yang difermentasi dengan Starbio, Aspergillus niger, Trichoderma viride, dan gabungan Aspergillus niger dengan Trichoderma viride. Hal ini disebabkan perlakuan P0 pakan tongkol jagung tanpa fermentasi memiliki kandungan serat kasar yang lebih tinggi sebesar 36\% dibandingkan dengan perlakuan P1, P2, P3 dan P4 yang difermentasi dengan Starbio yang mengalami penurunan serat kasar menjadi 22,5\%, Aspergillus niger 23,6\%, Trichoderma viride 24,1\% dan gabungan Aspergillus niger dengan Trichoderma viride 22,3\%. Penurunan serat kasar ini membuktikan adanya mikroba yang bekerja dalam proses fermentasi dalam menurunkan serat kasar karena sifat mikroba yang mampu mendegradasi serat kasar. Kadar 
serat kasar pakan yang lebih rendah diharapkan akan menghasilkan kecernaaan yang lebih tinggi. Menurut Despal (2000) serat kasar memiliki hubungan yang negatif dengan kecernaan. Semakin rendah serat kasar maka semakin tinggi kecernaan ransum.

Uji kontras ortogonal menunjukkan bahwa kecernaan serat kasar pada perlakuan P1 ransum tongkol jagung fermentasi Starbio 0,5\% memberikan pengaruh yang tidak berbeda nyata $(\mathrm{P}>0,05)$ dibandingkan dengan perlakuan $\mathrm{P} 2, \mathrm{P} 3$ dan $\mathrm{P} 4$. Hal ini menunjukkan hasil bahwa daya cerna domba terhadap serat kasar pakan tongkol jagung fermentasi dengan Starbio sama halnya dengan daya cerna tongkol jagung fermentasi dengan Aspergillus niger, Trichoderma viride, dan gabungan Aspergillus niger dengan Trichoderma viride. Ini dikarenakan pakan yang diberikan berupa pakan komplit yaitu pakan yang sudah disusun sesuai dengan kebutuhan ternak. Pakan perlakuan P1, P2, P3 dan P4 merupakan pakan dengan perlakuan tongkol jagung yang difermentasi terlebih dahulu sebelum diberikan kepada ternak domba. Dengan demikian mikroba dalam rumen akan bekerja dalam kondisi yang sama sehingga kecernaannya tidak berpengaruh nyata.

Uji kontras ortogonal menunjukkan bahwa kecernaan serat kasar pada perlakuan P2 dibandingkan P3 dan P4 tidak berpengaruh nyata $(\mathrm{P}>0,05)$ terhadap kecernaan serat kasar. Kecernaan terhadap serat kasar yang tidak berbeda nyata dipengaruhi oleh kandungan serat kasar dalam pakan dan kemampuan mikroorganisme dalam rumen domba. Hal ini sesuai dengan pernyataan Maynard et al (2005) bahwa daya cerna serat kasar dipengaruhi oleh beberapa faktor antara lain kadar serat dalam pakan, komposisi penyusun serat kasar dan aktivitas mikroorganisme.

Uji kontras ortogonal juga menunjukkan bahwa kecernaan serat kasar pada perlakuan P3 tidak nyata lebih tinggi $(\mathrm{P}>0,05)$ dari perlakuan $\mathrm{P} 4$. Hasil penelitian menunjukkan ratarata kecernaan $\mathrm{P} 3$ sebesar 44,07\% dan $\mathrm{P} 4$ 45,88\%. Hal ini didukung oleh pendapat Tilman et al. (2005) yang menyatakan bahwa kecernaan serat kasar tergantung pada kandungan serat kasar dalam ransum dan jumlah serat kasar yang dikonsumsi. Kadar serat kasar terlalu tinggi dapat mengganggu pencernaan zat lain.

\section{KESIMPULAN}

Penggunaan tongkol jagung yang difermentasi dengan bioaktifator (Starbio, Aspergillus niger, Trichoderma viride dan gabungan Aspergillus niger dan Trichoderma viride) memberikan pengaruh yang sangat berbeda nyata dibandingkan dengan tongkol jagung tanpa fermentasi dalam meningkatkan kecernaan protein kasar dan kecernaan serat kasar. Bioaktifator Starbio memberikan pengaruh yang sangat berbeda nyata dalam 
meningkatkan kecernaan protein kasar tetapi untuk kecernaan serat kasar tidak memberikan pengaruh yang berbeda nyata dibandingkan dengan bioaktifator lainnya.

\section{DAFTAR PUSTAKA}

Despal, disitasi oleh Herry Suprapto, FM 2013. Kecernaan Serat Kasar Dan Lemak Kasar Complete Feed Limbah Rami Dengan Sumber Protein Berbeda Pada Kambing Pernakan Etawa Lepas Sapih (Feed Composition). Universitas Jendral Soedirman, Purwokerto

Furqon, 2008. Statistik Terapan Untuk Penelitian. Bandung. Alfa Beta

Hardjo, S, N.S. Indrasti dan B. Tajuddin, 1989. Biokenveksi Pemanfaatan Limbah Industri Pertanian. Pusat Antar Universitas Pangan dan Gizi IPB, Bogor.

Hanafiah,2002. Rancangan Percobaan. Fak Pertanian. Universitas Sriwijaya. Palembang

Maynard, L.A, disitasi oleh R. H. Prawitasari , 2012. Kecernaan Protein Kasar Dan Serat Kasar Serta Laju Digesta Pada Ayam Arab Yang Diberi Ransum Dengan Berbagai Level Azolla Microphylla (Animal Nutrition). (7th Edition) McGraw-Hill Book Company. New York, USA. Mccutcheon, J. and D. Samples. 2002. Grazing Corn Residues.Extension Fact Sheet Ohio State University Extension.US.ANR10-02.

Rohaeni, E.S., N. Amali dan A. Subhan. 2006. Janggel jagung fermentasi sebagai pakan alternatif untuk ternak sapi pada musim kemarau.Pros. Lokakarya Nasional Jejaring Pengembangan Sistem Integrasi Jagung - Sapi. Pontianak, 9 - 10 Agustus 2006. Puslitbang Peternakan, Bogor. hlm. 193 - 196.

Sutardi, 1980. Kecernaan Nutrien pada Domba Lokal Jantan dan Kombinasi Berbagai Sumber Protein. Departemen Ilmu Nutrisi dan Teknologi Pakan. Fakultas Peternakan. Laporan Penelitian IPB. Bogor.

Tomaszeweska, M.W.J., M. Mastika., A. Djaya Negara., S. Gardiner dan T.R. Wiradarya. 1993. Produksi Kambing dan Domba di Indonesia. Universitas 11 Maret, Surabaya

Tillman, A.D., S. Reksohadiprodjo, S. Prawirokusumo dan S. Lebdosoekojo. 2005. Ilmu Makanan Ternak Dasar. Gadjah Mada University Press, Yogyakarta.

Wahyuni, 2009. Buku Penuntun Nutrisi dan Bahan Pakan Ternak. USU Press, Medan. 